\title{
Evaluation of Heavy Metals and Microbial Properties of Leachate and Hard Water Samples from Lemna Dumpsite in Calabar
}

\author{
Agbor R Bessong1*, Ubi S Emmanuel ${ }^{2}$ and Antai S Peter ${ }^{3}$ \\ ${ }^{1}$ Department of Genetics and Biotechnology, Environmental Biotechnology Unit, Faculty of Biological Sciences, University of \\ Calabar, Nigeria \\ ${ }^{2}$ Department of Civil Engineering, Cross River University of Technology, Nigeria \\ ${ }^{3}$ Department of Microbiology, University of Calabar, Nigeria \\ *Corresponding author: Agbor R Bessong, Department of Genetics and Biotechnology, Environmental Biotechnology Unit, Faculty \\ of Biological Sciences, University of Calabar, P.M.B Calabar, Cross River State, Nigeria
}

\section{ARTICLE INFO}

Received: 幽 November 02, 2021

Published: 慧 November 18, 2021

Citation: Agbor R Bessong, Ubi S Emmanuel, Antai S Peter. Evaluation of Heavy Metals and Microbial Properties of Leachate and Hard Water Samples from Lemna Dumpsite in Calabar. Biomed J Sci \& Tech Res 40(1)-2021. BJSTR. MS.ID.006399.

Abbreviations: WHO: World Health Organization; NDWQS: Nigeria Drinking Water Quality Standard; LSD: Least Significant Difference Test; NS: No Significance; THBC: Total Heterotrophic Bacteria Count; TCC: Total Coliform Count; TFC: Total Fungi Count; LSD: Least Significant Difference; H2S: Hydrogen Sulphides; WSA: Water Sample Containing Leachate; WSB: Water Sample Containing Hard Water

\begin{abstract}
This present study evaluated the levels of heavy metals and microbial properties of leachate and hard water samples obtained from lemna dumpsites. The heavy metals in leachate and hard water samples were determined using the WAGTECH photometer (Model 7100) for the analysis of iron, chromium, manganese, zinc, copper and aluminium while WAGTECH Arsernator Model W5000063 for the analysis of arsenic. Microbial population in samples were determined using standard microbiological procedures. The result showed that the leachate samples yielded the highest total heterotrophic bacteria counts of $6.2 \times 10^{5} \mathrm{CFU} / \mathrm{ml}$, while the hard water yielded the highest total coliform counts of $3.07 \times 10^{5} \mathrm{CFU} / \mathrm{ml}$ and total fungi count of $4.2 \times 10^{5} \mathrm{CFU} / \mathrm{ml}$. The prevalent bacteria species from the leachate and hard water samples were Streptococcus feacalis, Escherichia coli, Pseudomonas aeruginosa, Serratia marcensen, Staphylococcus aureus and Bacillus subtilis and four fungal species were identified: Penicillium spp, Aspergillus spp, Fusarium spp and Yeast spp. The result of the heavy metal analysis shows that the sequence of leachates content in the heavy metals determined in this study follows the trend: $\mathrm{Cu}>\mathrm{Al}>\mathrm{Zn}>\mathrm{Fe}>\mathrm{Cr}>\mathrm{Mn}>$ As while the sequence in hard water was $\mathrm{Fe}>\mathrm{Al}>$ $\mathrm{Cu}>\mathrm{Zn}>\mathrm{Mn}>\mathrm{Cr}>$ As having the lowest to be arsenic indicating absence of Arsenic in the hard water samples. This imply that virtually most of the parameters determined were above the World Health Organization/Nigeria Drinking Water Quality Standard permissible limits for drinking water. It was concluded that the levels of contaminants present in the dumpsite could be hazardous to the management staff of the dumpsite. Government should develop a sustainable plan for effective management and recycling of generated wastes to caution it impact on neighboring underground water table.
\end{abstract}

Keywords: Pollution; Leachate; Dumpsites; Hard-Water; Microbes; Lemna

\section{Introduction}

Solid waste management is of global concern in both developing and developed countries. Despite much awareness aimed at reducing the waste generated due to anthropogenic activities, there has been an increase in solid waste generation throughout the world [1]. This could partly be due to increase in population, industrialization and urbanization. Different efforts geared toward effective management of solid waste due to the perceived adverse health and environmental impacts have been reported [2]. 
Landfilling remains one of the most commonly used methods for solid waste management in most parts of the world. Its efficiency and safety coupled with cost make it the preferred method [3] Several advances in landfill technology have been reported to enhance its suitability for solid waste management. Leachate is defined as any contaminated liquid that is generated from water percolating through a solid waste disposal site, accumulating contaminants, and moving into subsurface areas. Leachate is often generated from landfill processes due to the increasing presence of soil moisture and other favorable environmental factors. In most developing countries, the facility for leachate collection and treatment is often not part of the design of landfill sites. One of the adverse effects caused by solid waste disposal onto landfills is the contamination of surface and groundwater by leachate. The extent of such contamination depends on the quality of leachate generated from the landfill. Solid wastes that constitute nuisance to the environment consist of household waste, construction and demolition debris of residence and street wastes generated from residential and commercial complexes. Garbage has often originated enormously from the rapid urbanization, changes in the life style and food habits, resulting in increase in the amount and types of solid waste [4].

In the absence of a confining barrier beneath or surrounding the waste disposal site, this leachate can migrate and contaminate subsurface and surface waters. The volume of leachate generated varies with the amount of precipitation and storm water run-on and run-off, the volume of groundwater entering the waste-containing zone, and the moisture content and absorbent capacity of the waste material. When leachate is collected via perforated pipes, rainfall significantly affects leachate volume and contaminant concentrations [5,6] listed SZ landfill age, ambient air temperature, precipitation and refuse permeability, depth, temperature, and waste composition as factors that affect leachate quantity and composition. It has been reported that leachate composition and strength vary widely from landfill to landfill and even within a given landfill. Variability in leachate volume and pollutant concentration is generally less predictable than variability in groundwater flow; hence the design of collection and treatment systems must include provisions for addressing uncertainty. In such instances, flow equalization may be used to offset variable leachate volume and contaminant loading. Leachate control should, therefore, be included in the design of solid waste management systems. The volume and flow rate of the leachates are dependent upon the percolation of water through the waste layers. The transfer of contaminants into the leachate and biodegradation processes is affected by the flow patterns and velocity of the leachate [7]. Percolation from the unsaturated zone into the saturated zone is thus possible, and this gives a pathway for groundwater contamination. Surface runoff through the landfill also provides a possible route to surface water contamination majorly during precipitation events.
The generation of leachate from landfills if not properly managed can lead to several adverse environmental and health impacts $[8,9]$. The risks of leachate generation can be mitigated by properly designed and engineered landfill sites, such as those that are constructed on geologically impermeable materials or sites that use impermeable liners made of geomembranes or engineered clay. In addition, most toxic and difficult materials are now specifically excluded from land filling. However, despite much stricter statutory controls, leachates from modern sites are often found to contain a range of contaminants stemming from illegal activity or legally discarded household and domestic products [10].

\section{Materials and Method}

Leachate and hard water samples were collected at Lemna dumpsite in Calabar Municipality, Cross River State. The leachate was collected from the base of the solid waste heap, the leachate drained from the heap as a result of gravity while the hard water sample was collected from the surrounding of Lemna dumpsite. The samples were transported to the laboratory for analysis.

\section{Microbial Analysis}

The total heterotrophic bacterial count (THB) was determined by cultural techniques i.e., by plating into nutrient agar (NA), and fungi by plating into Sabouraud dextrose agar. Ten (10) fold serial dilutions with one gram of the sample, $0.1 \mathrm{ml}$ of $10^{-4}$ dilution was placed on the plates in triplicate and incubation at $28^{\circ} \mathrm{C}$ for 18 hours and $37^{\circ} \mathrm{C}$ for 72 hours for bacteria and fungi respectively. The colonies were then counted and expressed as colony forming units per gram,

\section{Heavy Metal Analysis}

Estimation of the heavy metal content in the water sample was analyzed using the WAGTECH Photometer Model 7100 for the determination of Iron, Chromium, Manganese, Zinc, Copper and Aluminium; WAGTECH Arsenator Model W5000063 was used for the determination of Arsenic.

\section{Statistical Analysis}

Data collected were subjected to a one-way analysis of variance (ANOVA). While significant means were separated using least significant difference (LSD) test at 5\% probability level.

\section{Results and Discussion}

\section{Heavy Metal Content in Water Samples Collected from the Dumpsites}

The result as presented on Table 1 revealed different levels of leachate and hard water contents in water samples obtained from the Lemna dumpsite. The parameters used includes iron, chromium, manganese, zinc, copper, arsenic and aluminum. Comparing with the WHO/NDWQS standards high significant difference was 
observed in some heavy metals, with no significant difference in chromium and manganese. The Environmental Protection Agency (EPA) considers iron in water as a secondary contaminant, which means it does not have a direct impact on health. The secondary Maximum Contaminant Level set out by the WHO is 0.3 milligrams per litre. Iron present in the leachate samples was $2.31 \mathrm{mg} / \mathrm{l}$ exceeded the WHO/NDWQS standards of $0.3 \mathrm{mg} / \mathrm{l}$ while the Fe in hard water was $0.39 \mathrm{mg} / \mathrm{l}$ also above the set standard. Chromium and its compounds are toxic when inhaled and ingested. The EPA considers iron in water as a secondary contaminant, which means it does not have a direct impact on health. The Secondary Maximum Contaminant Level set out by the WHO is 0.05 milligrams per litre. Chromium in leachate was $0.54 \mathrm{mg} / \mathrm{l}$ higher than the WHO/NDWQS standards of $0.05 \mathrm{mg} / \mathrm{l}$ while the $\mathrm{Cr}$ in hard water was $0.01 \mathrm{mg} / \mathrm{l}$, therefore the level of chromium is not enough for contamination. Manganese toxicity can result in permanent neurological disorders known as manganese. The $\mathrm{Mn}$ in hard water was $0.012 \mathrm{mg} / \mathrm{l}$ while the $\mathrm{Mn}$ in the leachate was $0.0017 \mathrm{mg} / \mathrm{l}$ below the WHO/NDWQS standards of $0.1 \mathrm{mg} / \mathrm{l}$ making it partially fit for consumption. Zinc is an essential trace element with very low toxicity in humans.

Table 1: Heavy metal content in leachate and hard water samples.

\begin{tabular}{|c|c|c|c|c|c|}
\hline Parameters & Unit & Leachate & Hard Water & WHO/NDWQS (2009) & LSD \\
\hline Iron, $\left(\mathrm{Fe}^{+2 /+3}\right)$ & $\mathrm{Mg} / \mathrm{l}$ & $2.31^{\mathrm{a}} \pm 0.6$ & $0.39^{\mathrm{b}} \pm 0.008$ & 0.3 & 0.22 \\
\hline Chromium, $\left(\mathrm{Cr}^{+6}\right)$ & $\mathrm{Mg} / \mathrm{l}$ & $0.54 \pm 0.04$ & $0.01 \pm 0.001$ & 0.05 & NS \\
\hline Manganese, $\left(\mathrm{Mn}^{2+}\right)$ & $\mathrm{Mg} / \mathrm{l}$ & $0.0017 \pm 0.002$ & $0.012 \pm 0.0006$ & 0.1 & NS \\
\hline Zinc, $\left.\left(\mathrm{Zn}^{2+}\right)\right)$ & $\mathrm{Mg} / \mathrm{l}$ & $2.66^{\mathrm{a}} \pm 0.6$ & $0.07+ \pm 0.006$ & 3 & 0.22 \\
\hline Copper, $\left(\mathrm{Cu}^{2+}\right)$ & $\mathrm{Mg} / \mathrm{l}$ & $6.60^{\mathrm{a}} \pm 0.12$ & $0.34^{\mathrm{b}} \pm 0.006$ & 1 & 0.014 \\
\hline Arsenic, (As) & $\mu / 1$ & $0.01^{\mathrm{a}} \pm 0.003$ & $0.00^{\mathrm{b}} \pm 0.00$ & 10 & 0.32 \\
\hline Aluminum $\left(\mathrm{Al}^{3+}\right)$ & $\mathrm{Mg} / \mathrm{l}$ & $2.68^{a} \pm 0.12$ & $0.38^{\mathrm{b}} \pm 0.006$ & 0.2 & 0.32 \\
\hline
\end{tabular}

From the result, the $\mathrm{Zn}$ in the leachate samples was $2.66 \mathrm{mg} / \mathrm{l}$ while the $\mathrm{Zn}$ in hard water was $0.07 \mathrm{mg} / \mathrm{l}$ below the WHO/NDWQS standards which is $3 \mathrm{mg} / \mathrm{l}$ making it fit with a major significant difference between them. Copper present in leachate was $6.60 \mathrm{mg} / \mathrm{l}$ exceeded the WHO/NDWQS standards of $1 \mathrm{mg} / \mathrm{l}$ while $\mathrm{Cu}$ in the hard water was $0.34 \mathrm{mg} / \mathrm{l}$ did below the WHO/NDWQS standards. The leachate had Arsenic value of $0.01 \mathrm{mg} / \mathrm{l}$ while the hard water sample has Arsenic level of $0.00 \mathrm{mg} / \mathrm{l}$ below the WHO/NDWQS standards making it less injurious to human health. Aluminium present in the leachate was $2.68 \mathrm{mg} / \mathrm{l}$ and the hard water had $\mathrm{Al}$ of $0.38 \mathrm{mg} / \mathrm{l}$, these values exceeded the WHO/NDWQS standards of $0.2 \mathrm{mg} / \mathrm{l}$ which is unfit and ingestion by humans could cause serious health problems. The sequence of heavy metals in leachate samples determined in this study follows the trend: $\mathrm{Cu}>\mathrm{Al}>\mathrm{Zn}>$ $\mathrm{Fe}>\mathrm{Cr}>\mathrm{Mn}>\mathrm{As}$ while the sequence in hard water was $\mathrm{Fe}>\mathrm{Al}>$ $\mathrm{Cu}>\mathrm{Zn}>\mathrm{Mn}>\mathrm{Cr}>$ As having the lowest to be arsenic. The heavy metal content in the samples showed high significant differences. The LSD at 5\% showed that Arsenic and Aluminium had the highest significant difference followed by zinc and iron next to copper in that order, meanwhile, Chromium and Manganese had no least significant difference.

\section{Microbial Analysis of Water Samples Collected from the Dumpsites}

Table 2 show the mean total bacterial, coliform and fungi counts in samples from the dumpsite. The analysis therefore reveals total heterotrophic bacteria counts ranged from $5.67 \times 10^{5}$ $\mathrm{cfu} / \mathrm{ml}$ to $6.2 \times 10^{5} \mathrm{cfu} / \mathrm{ml}$, the highest bacteria counts was obtained in the leachate samples while the hard water had the least bacterial counts. Coliform counts ranged from $2.0 \times 10^{5} \mathrm{cfu} / \mathrm{ml}$ to $3.07 \times 10^{5}$ $\mathrm{cfu} / \mathrm{ml}$, the highest coliform counts were obtained in the hard water sample with mean of $3.07 \times 10^{5} \mathrm{cfu} / \mathrm{ml}$, significantly higher than the coliform counts in leachate sample $2.0 \times 10^{5} \mathrm{cfu} / \mathrm{ml}$. The mean total fungi count ranged from $3.0 \times 10^{5} \mathrm{cfu} / \mathrm{ml}$ to $4.2 \times 10^{5} \mathrm{cfu} / \mathrm{ml}$ in hard water sample, significantly higher than the fungi counts in leachate sample with a count of $3.0 \times 10^{5} \mathrm{cfu} / \mathrm{ml}$. The bacterial, coliform and fungal counts from the dumpsite samples showed significant differences. The least significant difference test at 5\% probability showed that the fungal counts was the highest, followed by the coliform and bacterial counts.

Table 2: Microbial counts of Lemna dumpsites.

\begin{tabular}{|c|c|c|c|}
\hline Parameters & Leachate & Hard water & LSD \\
\hline THBC $\left[\times 10^{5} \mathrm{cfu} / \mathrm{ml}\right]$ & $62 \mathrm{a} \pm 1.15$ & $56.7 \mathrm{~b} \pm 0.67$ & 3.72 \\
\hline TCC $\left[\times 10^{5} \mathrm{cfu} / \mathrm{ml}\right]$ & $20 \mathrm{~b} \pm 1.15$ & $30 \mathrm{a} \pm 1.76$ & 5.9 \\
\hline TFC $\left[\times 10^{5} \mathrm{cfu} / \mathrm{ml}\right]$ & $30 \mathrm{~b} \pm 1.73$ & $42 \mathrm{a} \pm 1.15$ & 11.9 \\
\hline
\end{tabular}

\section{Cultural Characterization and Identification of Microbial Isolates}

The microbial isolates were identified on the basis of their cultural cellular morphology, gram's reaction, biochemical characterization and net mount techniques. The tentative bacteria and coliform isolates from the various samples were Escherichia coli, Pseudomonas aeruginosa, Serratia and Staphylococcus aureus. 
The above organisms were confirmed after a careful comparism of the various test results carried out with the Bergy manual for bacteriological identification. Meanwhile, the fungi isolates include Penicillium spp, Yeast spp, Aspergillus spp and Fusarium spp they were confirmed using the mycological manual for fungi identification (Tables $3 \& 4$ ).

Table 3: Cultural characterization, cell morphology, gram's reaction and biochemical characterization of bacteria isolates.

\begin{tabular}{|c|c|c|c|c|c|c|c|c|c|c|c|c|c|c|c|c|c|c|c|c|}
\hline $\begin{array}{l}\text { Sample } \\
\text { Code }\end{array}$ & $\begin{array}{l}\text { Isolate } \\
\text { Number }\end{array}$ & $\begin{array}{c}\text { Cultural } \\
\text { characterization } \\
\text { of bacteria } \\
\text { isolates }\end{array}$ & $\begin{array}{c}\text { Cell } \\
\text { morphology } \\
\text { and shape }\end{array}$ & 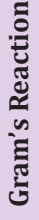 & $\sum^{3}$ & $\frac{0}{0}$ & 莣 & 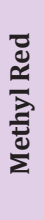 & 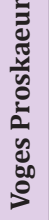 & 莺 & 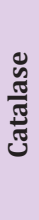 & 离 & 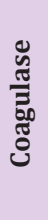 & ֻँ & 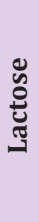 & ญू & ¿্் & 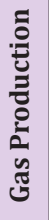 & Nี & $\begin{array}{l}\text { Probable } \\
\text { Organism }\end{array}$ \\
\hline \multirow[t]{5}{*}{ WSA } & 1 & $\begin{array}{l}\text { Large, mucoid, } \\
\text { spherical and flat }\end{array}$ & Cocci in chain & + & - & - & - & - & + & - & - & - & - & - & + & + & + & + & - & $\begin{array}{l}\text { Streptococcus } \\
\text { faecalis }\end{array}$ \\
\hline & 2 & $\begin{array}{l}\text { Smooth, circular, } \\
\text { complex, mucoid } \\
\text { colony }\end{array}$ & Short rod & - & + & + & + & + & - & - & + & - & - & - & + & + & + & + & - & Escherichia coli \\
\hline & 3 & $\begin{array}{l}\text { Greenish, } \\
\text { pigmented, } \\
\text { smooth and } \\
\text { circular }\end{array}$ & Curved red & - & + & - & - & + & - & + & + & + & - & - & - & - & - & - & - & $\begin{array}{l}\text { Pseudomonas } \\
\text { aeruginosa }\end{array}$ \\
\hline & 4 & $\begin{array}{l}\text { Red pigmented, } \\
\text { smooth, round } \\
\text { colony }\end{array}$ & Small tiny rod & - & + & - & - & + & - & + & + & - & - & - & - & - & + & - & - & $\begin{array}{c}\text { Serratia } \\
\text { marcescen }\end{array}$ \\
\hline & $=$ & & & & & & & & & & & & & & & & & & & \\
\hline \multirow[t]{3}{*}{ WSB } & 1 & $\begin{array}{l}\text { Smooth, raised, } \\
\text { spherical and } \\
\text { glistening colony }\end{array}$ & $\begin{array}{l}\text { Cocci in } \\
\text { clusters }\end{array}$ & + & - & - & + & - & + & - & + & - & + & - & - & - & + & - & - & $\begin{array}{c}\text { Staphylococcus } \\
\text { aureus }\end{array}$ \\
\hline & 2 & $\begin{array}{l}\text { Irregular, milky, } \\
\text { flat, large colony }\end{array}$ & Baccilli rod & + & + & - & + & - & + & + & + & + & - & - & - & - & + & - & + & Bacillus subtilis \\
\hline & 3 & $\begin{array}{l}\text { Smooth, circular, } \\
\text { convex, mucoid } \\
\text { colony }\end{array}$ & $\begin{array}{l}\text { Single short } \\
\text { rod }\end{array}$ & - & + & + & + & + & - & - & + & - & - & - & + & + & + & + & - & Escherichia coli \\
\hline
\end{tabular}

Table 4: Cultural characterization and identification of fungi isolates.

\begin{tabular}{|c|c|c|c|c|}
\hline $\begin{array}{l}\text { Sample } \\
\text { Code }\end{array}$ & $\begin{array}{l}\text { Isolate } \\
\text { Number }\end{array}$ & $\begin{array}{l}\text { Microscopic or Cultural } \\
\text { Characteristics }\end{array}$ & Microscopic Features & Probable Fungi \\
\hline \multirow{4}{*}{ WSA } & 1 & $\begin{array}{l}\text { Colony was shades of green velvety } \\
\text { appearance and wrinkled and grows } \\
\text { moderately. }\end{array}$ & $\begin{array}{l}\text { The conidiophore produced head, composed } \\
\text { of short branches and bearing. Phialides that } \\
\text { are arranged in brush-like pattern. }\end{array}$ & Penicillium spp \\
\hline & 2 & $\begin{array}{l}\text { Colony was shades of brown, velvety } \\
\text { colony that grows rapidly with spores }\end{array}$ & $\begin{array}{l}\text { Narrow spherical head that is curved with } \\
\text { phialides and septate hyphae }\end{array}$ & Aspergillus spp \\
\hline & 3 & $\begin{array}{l}\text { rapid growing colony woolly to cotton- } \\
\text { like in appearance and fast spreading }\end{array}$ & $\begin{array}{l}\text { The conidiophore occurred in sickled cell } \\
\text { shape and produced conidia that are multicell }\end{array}$ & Fusarium spp \\
\hline & 4 & $\begin{array}{l}\text { Colony was white to creamy, soft, smooth } \\
\text { and bacteria-like in appearance }\end{array}$ & $\begin{array}{l}\text { Oval and elongated cells with buds attached } \\
\text { to the mother cell and in chains }\end{array}$ & Yeast spp \\
\hline \multirow[t]{2}{*}{ WSB } & 1 & $\begin{array}{c}\text { Colony was shades of green, velvety } \\
\text { in appearance, wrinkled and grows } \\
\text { moderately }\end{array}$ & $\begin{array}{l}\text { The conidiophore produced head composed } \\
\text { of short branches and bearing phialides that } \\
\text { are arranged in brush-like pattern }\end{array}$ & Penicillin spp \\
\hline & 2 & $\begin{array}{l}\text { Colony was white to creamy, soft, smooth } \\
\text { and bacteria-like in appearance }\end{array}$ & $\begin{array}{l}\text { Oval and elongated yeast cell with buds } \\
\text { attached to the mother cell and in chain }\end{array}$ & Yeast spp \\
\hline
\end{tabular}

\section{Discussion}

Lemna solid waste dumpsite is an unlined, uncontrolled planned and open dumpsite. This dumpsite harbored E-wastes, agricultural wastes, medical wastes and all forms of hazardous wastes. A discussion is provided in Table 1 regarding the maximum limit of contaminants in leachate and hard water prior to its disposal into the environment. However, due to extreme variation of leachate composition and operating conditions in different landfills, no guideline or standard operating procedures for leachate treatment and disposal can be effectively chalked out. Solid waste are being 
sorted out into biodegradable and non-biodegradable wastes as is the practice in developed countries due to the current management availed to the control of waste deposited in the environment. Industrial waste which normally contains toxic chemicals and sometimes radio-active substances including electronic wastes, are dumped together with domestic, market and commercial wastes, when mashed together generates fluids known as leachate during the dry and wet season there is a constant run-off from this compost. In this compost, there is presence of bacteria, fungi, and other pathogens including the presence of heavy metals. It is known that the run-of is connected to major water pathways which causes contamination and makes it unfit for consumption. The observed characteristics of leachate and heavy metal contaminated water samples maybe associated with the heavy rainfall that occurs during the rainy season and liquid content present in the waste which might encourage the leaching of the pollutants in the surrounding water.

The present observation indicates that the water samples are indeed polluted when compared with the World Health Organization and Nigerian Drinking Water Quality standards. Additionally, the extent of the pollution of the groundwater increases with decreasing distance from the landfill. Inorganic and heavy metals have been reported to be retained at a lower level than organic chemicals and pesticides $[11,12]$, also reported that the concentrations of pollutants in leachate vary with depth of groundwater and the distance from the landfill. Generally, the total bacteria population of the water samples is higher in wet season than in dry season, this observation is evident in the study conducted out by Hammond and Beliles [13]. The presence of coliform bacteria in the water samples as observed in this study is a source of concern. These bacteria have been associated with a number of health problems such as cholera, vomiting and diarrhoea [14]. The use of leachate contaminated water for domestic purposes may cause several pathological diseases as indicated earlier. Presence of E. coli and total coliform bacteria indicates microbial pollution of the groundwater by anthropogenic activities. All bacterial isolates recovered from the waste dumpsite samples except Serratia spp are directly implicated in food-borne infections such as diarrhoea, typhoid and gastroenteritis. The usual disease pathway includes placing contaminated hands in the mouth or eating food, through vector insects such as cockroaches or mosquitoes or directly inhaling airborne dust particles contaminated with pollutants.

The study further revealed that the concentration of waste materials in the landfill site had systematically polluted the soil and groundwater over time. The effect of such pollution as determined from the study declined away from the polluting source. This implied that the contamination of the surrounding water was more dependent on proximity to dump sites. The less dependency has been attributed to the influence of topography, type, state of waste disposal systems and to some extent, the hydrogeology of the area.

\section{Conclusion}

The level of pollution, seepage into surrounding water at the dumpsite was studied by sampling water at the dumpsite containing leachate and heavy metals to reveal the microbial properties, heavy metal contents, characterization. The study revealed that the composition and disposal of solid waste in Calabar metropolis potentially have environmental and public health implications. Therefore, it is pertinent to conclude that the open waste dump at the lemna dumpsite constitute a source of microbial and toxic chemical contamination of the dumpsite. The dumpsite has to a greater extent influenced the pollution or contamination of the surface water bodies within the vicinity.

\section{Acknowledgement}

We acknowledged all researchers whose articles were cited during this research and appreciate my co-authors for their contributions in make up this article.

\section{References}

1. Naveen BP, Mahapatra DM, Sitharam TG, Sivapullaiah PV, Ramachandra TV, et al. (2016) Physiochemical and biological characterization of urban municipal landfill leachate. Environmental Pollution 220: 1-12.

2. Kassim SM (2012) The importance of recycling in solid waste management. Macromolecular Symposia 320(1): 43-50.

3. Krcmar D, Tenodi S, Giba N, Kerkez D, Watson M, et al. (2018) Premedial assessment of the municipal landfill pollution impact 9on soil and shallow groundwater in Subotica, Serbia. Science of the total Environment 615: 1341-1354.

4. El-Fadel M, Findikakis AN, Leckie JO (1997) Environmental impacts of solid waste land filling. Journal of Environment Management 50(1): $1-25$.

5. Elsevier BV (2019) Leachate. Science Direct 23: 1-20.

6. Nicholas PC (2008) Treating contaminated groundwater and leachate Science Direct 7: 259-308.

7. Zeiss C, Ugucioni M (1994) Mechanisms and patterns of leachate flow in municipal solid waste landfills. Journal of Environmental Systems 23(3): 247-270.

8. Eggen I, Moeder M, Arukwe A (2010) Municipal landfill leachate: A significant source for new and emerging pollutants. Science of the Total Environment 408(21): 5147-5157.

9. Agbor RB, Ekpo IA, Ekaluo UB, Okpako EC, Okigbo AU, et al. (2013) Groundwater quality assessment of some selected boreholes in Calabar. World Rural Observations 5(3): 37-41.

10. Singh A, Chandra S, Kumar G, Chauhan LK, Kumar R, et al. (2007) Mutagenicity of leachates from industrial solid wastes during salmonella reverse mutation assay. Ecotoxicology Environmental Safety 66(2): 210216.

11. Brenaam MB (2000) Water works: Research accelerates on advanced water treatment technologies as their use in purification grows. Groundwater Journal 3: 14-21. 
12. Johnson R, Pankow J, Bender D, Prince C, Zogorski J, et al. (2000) Question: To what extent will post releases contaminate community water supply wells? International Journal of Environmental Science Technology 34: 210A-217A.

\section{ISSN: 2574-1241}

DOI: 10.26717/BJSTR.2021.40.006399

Agbor R Bessong. Biomed J Sci \& Tech Res

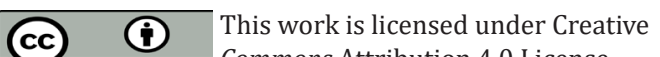

Submission Link: https://biomedres.us/submit-manuscript.php
13. Prescott LM, Harley JP, Klein DA (2002) Urinary tract infection. Microbiology Journal 5: 15-17.

14. (2009) World Health Organization (WHO). Public health significance. Geneva: World Health Organization.

$\begin{array}{ll}\text { BIOMEDICAL } & \text { Assets of Publishing with us } \\ \text { RESEARCHES } & \text { - Global archiving of articles } \\ \text { - Immediate, unrestricted online access }\end{array}$

